\title{
Emended descriptions of the genus Micrococcus, Micrococcus luteus (Cohn 1872) and Micrococcus lylae (Kloos et al. 1974)
}

${ }^{1}$ Institut für Mikrobiologie und Genetik, Universität Wien, A-1030 Wien, Austria

2 Institut für Bakteriologie, Mykologie und Hygiene, Veterinärmedizinische Universität, A-1210 Wien, Austria

${ }^{3}$ Institut für Angewandte Mikrobiologie, JustusLiebig-Universität, D-35390 Giessen, Germany

${ }^{4}$ DSMZ-Deutsche Sammlung von Mikroorganismen und Zellkulturen $\mathrm{GmbH}$, D-38124 Braunschweig, Germany

${ }^{5}$ Biotechnology Research Centre, LaTrobe University, Bendigo, Victoria 3550, Australia

${ }^{6}$ Institute of Genetics and General Biology, University of Salzburg, A-5020 Salzburg, Austria

\author{
Monika Wieser, ${ }^{1,2}$ Ewald B. M. Denner, ${ }^{1}$ Peter Kämpfer, ${ }^{3}$ \\ Peter Schumann, ${ }^{4}$ Brian Tindall, ${ }^{4}$ Ulrike Steiner, ${ }^{4}$ Dietmar Vybiral, ${ }^{1}$ \\ Werner Lubitz, ${ }^{1}$ A. M. Maszenan, ${ }^{5}$ B. K. C. Patel, ${ }^{5}$ Robert J. Seviour, ${ }^{5}$ \\ Christian Radax ${ }^{6}$ and Hans-Jürgen Busse ${ }^{1,2}$
}

\begin{abstract}
Author for correspondence: Hans-Jürgen Busse. Tel: +43 125077 2128. Fax: +431250772190. e-mail: Hans-Juergen.Busse@vu-wien.ac.at
\end{abstract}

\begin{abstract}
Nine yellow-pigmented, spherical bacterial strains isolated from a medieval wall painting (strain D7), from indoor air (strains 3, 6, 7, 13C2, 38, 83 and 118) and from an activated-sludge plant (strain Ballarat) were classified by a polyphasic approach. Analyses of the 16S rRNA gene sequences of three representatives (strains D7, 118 and Ballarat) indicated that they all belong to the genus Micrococcus. The three isolates shared the highest sequence similarities with Micrococcus luteus DSM 20030' (97.9-98\%), Micrococcus antarcticus AS $1.2372^{\top}(97 \cdot 9-98 \cdot 3 \%)$ and Micrococcus lylae DSM $20315^{\top}$ (97.5-97.9\%). DNA-DNA reassociation studies clearly demonstrated that all nine isolates belong to the species M. luteus. However, neither their chemotaxonomic features nor their physiological and biochemical properties were consistent with those of $M$. luteus DSM $20030^{\top}$. In contrast to $M$. luteus DSM 20030', all isolates investigated possessed $M K-8\left(H_{2}\right)$ as the major respiratory quinone, and strain Ballarat had an A4 $\alpha$ peptidoglycan type. On the basis of analyses of their Fourier transform-infrared spectroscopy spectra, isolates $\mathrm{D} 7,3,6,7,13 \mathrm{C} 2,38,83$ and 118 could be grouped into a single cluster separate from M. luteus DSM 20030', strain Ballarat and M. Iylae DSM 20315'. In addition, all these isolates could be distinguished from $M$. luteus DSM $20030^{\top}$ by their ability to assimilate D-maltose, D-trehalose, DL-3hydroxybutyrate, DL-lactate, pyruvate and L-histidine and to hydrolyse casein. Strains D7, 3, 6, 7, 13C2, 38, 83 and 118 differed from both $M$. luteus DSM $20030^{\top}$ and strain Ballarat by their ability to assimilate acetate, L-phenylalanine, L-serine and phenylacetate. Furthermore, REP-PCR fingerprinting yielded one common band for these strains, whereas this band was not observed for $M$. Iuteus DSM 20030', strain Ballarat or M. lylae DSM $20315^{\top}$. On the basis of these data, the species $M$. Iuteus can be divided into three biovars that are distinguished by several chemotaxonomic and biochemical traits: biovar I, represented by M. Iuteus DSM 20030'; biovar II, represented by strains D7 (= DSM $14234=$ CCM 4959), 3, 6, 7, 13C2, 38, 83 and 118; and biovar III, represented by strain Ballarat (= DSM $14235=$ CCM 4960). On the basis of the results generated in this study, emended descriptions of the genus Micrococcus and the species M. luteus and M. Iylae are given.
\end{abstract}

Keywords: Micrococcus luteus, 16S rRNA gene sequence, chemotaxonomy, physiological/biochemical traits

Abbreviations: pNA, p-nitroanilide; pNP, p-nitrophenyl; FT-IR, Fourier transform-infrared spectroscopy.

The GenBank/EMBL/DDBJ accession numbers for the 16S rDNA sequences of the Micrococcus luteus strains D7, 118 and Ballarat are respectively AJ409095, AJ312751 and AJ409096. 


\section{INTRODUCTION}

The genus Micrococcus was first described by Cohn (1872). The description of the genus has been revised several times. Baird-Parker (1965) divided the aerobic, catalase-positive, Gram-positive cocci into two groups. Strains fermenting glucose were placed into group 1 and were later described as members of the genus Staphylococcus. Those utilizing glucose oxidatively, or not at all, were placed in group 2 (the genus Micrococcus). Rosypal et al. (1966) proposed a classification into groups based on the $\mathrm{G}+\mathrm{C}$ content of the genomic DNA. Strains with a $\mathrm{G}+\mathrm{C}$ content within the range $30 \cdot 7-36 \cdot 4 \mathrm{~mol} \%$ were classified in the genus Staphylococcus, whereas it was proposed that strains with a $\mathrm{G}+\mathrm{C}$ content within the range $66.3-73.3 \mathrm{~mol} \%$ belonged to the genus Micrococcus. Subsequently, the genus Micrococcus was extended to include the species Micrococcus lylae, Micrococcus kristinae, Micrococcus nishinomiyaensis, Micrococcus sedentarius and Micrococcus halobius (Onishi \& Kamekura, 1972; Kloos et al., 1974; Kocur et al., 1975). Later, 16S rDNA sequence analysis and chemical studies led to the fragmentation of the genus Micrococcus and the proposal of four new genera - Kocuria, Nesterenkonia, Kytococcus and Dermacococcus - while only two species, Micrococcus luteus and M. lylae, were considered to represent the genus Micrococcus (Stackebrandt et al., 1995). Recently, a cold-adapted bacterium has also been shown to belong to the genus Micrococcus, and the name Micrococcus antarcticus was proposed for this micro-organism (Liu et al., 2000).

During the investigation of bacteria isolated from indoor air (Camuffo et al., 1999), a wall painting and an activated-sludge plant, some bacterial isolates were obtained that were shown, by $16 \mathrm{~S}$ rDNA sequence analysis, to be affiliated phylogenetically with the species $M$. luteus, but which clearly differed from it in terms of certain chemotaxonomic features and biochemical properties. Nevertheless, we demonstrate here that these isolates in fact represent biovars of the species M. luteus.

\section{METHODS}

Bacterial strains and cultural conditions. Strain D7 was isolated from a medieval wall painting in the chapel of Herberstein Castle in Styria, Austria. The airborne isolates 3, 6, 7, 13C2, 38, 83 and 118 were collected in the 'Museo Correr' in Venice, Italy, by using the Biotest Hycon air sampler Reuter-Centrifugal-Sampler Plus (Camuffo et al., 1999). Strain Ballarat was isolated from an activated-sludge plant in Ballarat, a city in the state of Victoria, Australia. All isolates were subcultivated on PYES-agar plates $\left[1^{-1}: 3 \mathrm{~g}\right.$ peptone from casein, $3 \mathrm{~g}$ yeast extract, $2.3 \mathrm{~g}$ disodium succinate, $15 \mathrm{~g}$ agar (all from Merck), $\mathrm{pH} 7 \cdot 2$ ] and incubated at room temperature. The strains used for comparison were M. luteus DSM 20030 and M. lylae DSM 20315 .

Morphological, physiological and biochemical characterization. Cell morphology was determined using phase-contrast microscopy. Gram-staining and the $\mathrm{KOH}$ test were performed as described previously (Moaledj, 1986). Catalase activity was detected by dropping $3 \% \mathrm{H}_{2} \mathrm{O}_{2}$ onto welldeveloped colonies on agar plates and observing any gas bubbles produced. Oxidase activity was tested using Bactident Oxidase strips (Merck) according to the instructions of the manufacturer, and by using the method of Faller \& Schleifer (1981). Carbon-source utilization tests and qualitative enzyme assays were carried out in microtitre plates as described previously (Kämpfer et al., 1991). Nitrate reduction, urease activity, the production of indole and hydrogen sulfide, the metabolism of citrate as well as aerobic acid production from carbohydrates and the hydrolysis of casein, starch, gelatin, Tween 20 and Tween 80 were tested as described by Smibert \& Krieg (1994). $\mathrm{pH}$ tolerance was tested from $\mathrm{pH} 6$ to $\mathrm{pH} 10$ on buffered media (Nielson et al., 1995) and $\mathrm{NaCl}$ tolerance was measured at concentrations between 1 and $10 \%(\mathrm{w} / \mathrm{v})$.

16S rDNA sequence analysis. The $16 \mathrm{~S}$ rRNA genes from isolates D7, 118 and strain Ballarat were amplified, purified and sequenced as described by Wieser et al. (1999) and Maszenan et al. (1997). The sequences derived were aligned and compared with those of other bacterial 16S rDNA sequences available in the EMBL database by using the GCG FASTA program.

Nucleotide sequence accession numbers. The accession numbers for the reference sequences used are as follows: M38242 (M. luteus DSM 20030 ${ }^{\mathrm{T}}$ ), X80750 (M. lylae DSM $20315^{\mathrm{T}}$ ) and AJ005932 (M. antarcticus AS $1.2372^{\mathrm{T}}$ ).

DNA isolation and characterization. Isolation of DNA from acetone-pre-washed biomass and DNA-DNA hybridization were performed as described previously (Wieser et al., 1999). REP-PCR was performed as described by Louws et al. (1994). The G + C content of DNA ( $\mathrm{mol} \%$ ) was determined by using HPLC, according to Kaneko et al. (1986).

Chemotaxonomic investigations. Menaquinones, polar lipids and diagnostic cell-wall diamino acids were extracted and analysed as described previously (Wieser et al., 1999). Cellular fatty acid methyl esters were analysed according to Huys et al. (1997). Analysis of the peptidoglycan type was done as described by Groth et al. (1996).

Fourier transform-infrared (FT-IR) spectroscopy. Bacterial films for FT-IR spectroscopy were prepared from strains D7, 3, 6, 7, 38, 83, 118 and strain Ballarat, as well as from the type strains of $M$. luteus and $M$. lylae, grown on tryptic soy agar (Oxoid) at $28^{\circ} \mathrm{C}$ for $48 \mathrm{~h}$, by resuspending one loopful of cells in $80 \mu \mathrm{l}$ deionized water and applying an aliquot of $35 \mu 1$ to a predefined sample area on a zinc selenite optical plate. The samples were dried under reduced pressure to give a homogeneous film. The IR spectra were recorded in transmission mode between wave numbers 4000 and $500 \mathrm{~cm}^{-1}$ in an FT-IR spectrometer type IFS 28/B (Bruker), as described by Helm et al. (1991a, b). Data acquisition and analysis were carried out using the opUs 3.0 software for bacterial identification from the same manufacturer. Mean spectra were calculated from six to nine independent measurements of $M$. luteus DSM 20030 ${ }^{\mathrm{T}}$, M. lylae DSM $20315^{\mathrm{T}}$, strain Ballarat and strain 38, and from four to five independent measurements of the remaining strains. First derivatives of the spectra were compared with the hierarchical cluster-analysis methods implemented in oPUs 3.0; the spectral frequency ranges compared were nearly complete $\left(4000-700 \mathrm{~cm}^{-1}\right)$ or were combinations of spectral windows W1-W5 (Helm et al., 1991a). 


\section{RESULTS AND DISCUSSION}

\section{Morphological and cultural characteristics}

All of the strains that we studied were Gram-positive, catalase- and oxidase-positive cocci, mostly arranged in tetrads. They grew in circular, entire, convex and creamy yellow-pigmented colonies having diameters of approximately $4 \mathrm{~mm}$ after 2-3 days on PYES-agar plates at $37^{\circ} \mathrm{C}$.

\section{Physiological and biochemical characteristics}

The differentiating physiological and biochemical properties of isolates $\mathrm{D} 7,3,6,7,13 \mathrm{C} 2,38,83,118$ and Ballarat, as well as those of $M$. luteus DSM $20030^{\mathrm{T}}$ and M. lylae DSM 20315 , are summarized in Table 1. In contrast to M. luteus DSM $20030^{\mathrm{T}}$, all of the isolates investigated assimilated D-maltose, D-trehalose, DL-3hydroxybutyrate, DL-lactate, pyruvate and L-histidine and hydrolysed casein. Isolates D7, 3, 6, 7, 13C2, 38,

Table 1. Physiological and biochemical properties that differentiate $M$. antarcticus AS1.2372 ${ }^{\top}$, M. luteus DSM 20030', M. Iylae DSM $20315^{\top}$ and the novel isolates

+ , Positive; - , negative; (+), weakly positive; y, yellow; w, white; ND, data not available. Data for M. antarcticus are from Lui et al. (2000).

\begin{tabular}{|c|c|c|c|c|c|c|c|c|c|c|c|c|}
\hline Property & $\begin{array}{c}\text { M. antarcticus } \\
\text { AS1.2372 }^{\mathrm{T}}\end{array}$ & $\begin{array}{c}\text { M. lylae } \\
\text { DSM 20315 }\end{array}$ & $\begin{array}{c}\text { M. luteus } \\
\text { DSM 20030 }\end{array}$ & D7 & 3 & 6 & 7 & $13 \mathrm{C} 2$ & 38 & 83 & 118 & Ballarat \\
\hline Pigmentation & $\mathrm{Y}$ & $\mathrm{W}$ & $\mathrm{Y}$ & $\mathrm{Y}$ & $\mathrm{Y}$ & $\mathrm{Y}$ & $\mathrm{Y}$ & $\mathrm{Y}$ & $\mathrm{Y}$ & $\mathrm{Y}$ & $\mathrm{Y}$ & $\mathrm{Y}$ \\
\hline Urease & - & - & + & + & - & - & + & - & - & - & - & + \\
\hline Growth at $\mathrm{pH} 6$ & ND & - & - & + & - & $(+)$ & + & $(+)$ & $(+)$ & + & $(+)$ & - \\
\hline \multicolumn{13}{|l|}{ Assimilation of: } \\
\hline D-Mannose & - & - & + & + & + & + & + & + & + & + & + & + \\
\hline D-Maltose & - & + & - & + & + & + & + & + & + & + & + & + \\
\hline D-Trehalose & - & + & - & + & + & + & + & + & + & + & + & + \\
\hline D-Xylose & - & - & - & - & - & - & + & - & - & - & - & - \\
\hline Adonitol & ND & - & - & - & - & - & + & - & - & - & - & - \\
\hline$i$-Inositol & ND & - & - & - & + & - & - & - & - & - & - & - \\
\hline Maltitol & ND & + & + & + & + & - & + & + & + & + & + & - \\
\hline D-Mannitol & ND & - & - & - & - & - & - & - & - & + & - & - \\
\hline D-Sorbitol & - & - & - & - & - & - & - & - & - & + & - & - \\
\hline Putrescine & ND & - & - & + & + & + & + & - & + & + & + & - \\
\hline Acetate & - & + & - & + & + & + & + & + & + & + & + & - \\
\hline Propionate & - & - & + & + & + & + & + & + & + & + & + & - \\
\hline 4-Aminobutyrate & ND & - & - & + & + & + & + & - & - & + & - & + \\
\hline Citrate & ND & + & - & - & - & - & - & - & + & - & - & - \\
\hline Fumarate & ND & + & - & + & + & - & + & + & + & + & + & + \\
\hline Glutarate & ND & - & - & - & - & - & - & - & + & - & - & - \\
\hline DL-3-Hydroxybutyrate & ND & + & - & + & + & + & + & + & + & + & + & + \\
\hline DL-Lactate & ND & + & - & + & + & + & + & + & + & + & + & + \\
\hline L-Malate & + & - & - & - & - & - & - & - & + & - & - & - \\
\hline Oxoglutarate & ND & - & - & - & - & - & - & - & - & - & - & + \\
\hline Pyruvate & - & + & - & + & + & + & + & + & + & + & + & + \\
\hline L-Alanine & + & - & - & + & + & - & - & - & + & - & - & - \\
\hline L-Aspartate & + & + & + & + & + & - & + & + & + & + & + & - \\
\hline L-Histidine & $\mathrm{ND}$ & + & - & + & + & + & + & + & + & + & + & + \\
\hline L-Leucine & ND & + & - & - & - & - & - & - & - & - & - & - \\
\hline L-Phenylalanine & ND & - & - & + & + & + & + & + & + & + & + & - \\
\hline L-Proline & ND & - & - & - & - & - & + & - & - & - & - & + \\
\hline L-Serine & ND & - & - & + & + & + & + & + & + & + & + & - \\
\hline 3-Hydroxybenzoate & ND & + & - & - & - & - & - & - & - & - & - & - \\
\hline 4-Hydroxybenzoate & ND & + & - & - & - & - & - & - & - & - & - & - \\
\hline Phenylacetate & ND & - & - & + & + & + & + & + & + & + & + & - \\
\hline \multicolumn{13}{|l|}{ Hydrolysis of: } \\
\hline L-Proline pNA & ND & + & + & + & + & + & + & + & + & + & + & - \\
\hline Tween 20 & + & + & + & + & + & + & - & + & + & + & + & + \\
\hline Tween 80 & + & + & - & - & - & - & - & - & + & + & - & - \\
\hline Casein & ND & - & - & + & + & + & + & + & + & + & + & + \\
\hline
\end{tabular}


Table 2. Similarity matrix based on DNA-DNA hybridization data

Values are percentages of reassociation.

\begin{tabular}{|lcc|}
\hline Strain & D7 & Ballarat \\
\hline D7 & 100 & $87 \cdot 5$ \\
M. luteus DSM 20030 & $77 \cdot 4$ & $82 \cdot 5$ \\
M. lylae DSM 20315 & $48 \cdot 1$ & $44 \cdot 7$ \\
3 & $78 \cdot 3$ & $86 \cdot 7$ \\
6 & $95 \cdot 4$ & - \\
7 & $88 \cdot 7$ & - \\
13 C2 & $84 \cdot 2$ & - \\
38 & $83 \cdot 2$ & - \\
83 & $113 \cdot 6$ & - \\
118 & $106 \cdot 7$ & - \\
Ballarat & $87 \cdot 5$ & 100 \\
\hline
\end{tabular}

83 and 118 differed from both strain Ballarat and $M$. luteus DSM $20030^{\mathrm{T}}$ in their ability to assimilate acetate, L-phenylalanine, L-serine and phenylacetate.

\section{S rDNA sequencing}

The genus Micrococcus currently encompasses three species, M. luteus, M. lylae and M. antarcticus. These three are phylogenetically closely related to each other, although their status as separate species has been demonstrated by DNA relatedness (Schleifer et al., 1979; Stackebrandt et al., 1995; Liu et al., 2000). It should be noted that $16 \mathrm{~S}$ rDNA sequence similarity values obtained between these three species are higher than the value of $94.4 \%$ reported by Liu et al. (2000). Analyses of the 16S rDNA of strains D7, 118 and Ballarat resulted in respective fragments of 1430 bases (positions 54-1505, Escherichia coli numbering; Brosius et al., 1978), 1432 bases (53-1506) and 1424 bases (72-1507). The sequences of the three isolates shared the highest degrees of similarity to sequences of the type strains of $M$. luteus $(97.9,97.9$ and $98 \%), M$. lylae $(97 \cdot 7,97.5$ and $97.9 \%$ ) and $M$. antarcticus $(98.0$, 97.9 and $98.3 \%$ ). Strain D7 exhibited a $16 \mathrm{~S}$ rDNA sequence similarity of $99 \cdot 3 \%$ to strain 118 and of $99.0 \%$ to strain Ballarat, which shared a sequence similarity of $98.9 \%$ with strain 118 . In agreement with this clustering, strains $M$. luteus DSM $20030^{\mathrm{T}}$, M. lylae DSM 20315 $5^{\mathrm{T}}$, D7, 118 and Ballarat showed all the signature nucleotides specific to the family Micrococcaceae (Stackebrandt et al., 1997), except those at positions $640,839,847$ and 859 (E. coli numbering), where the nucleotides $\mathrm{U}, \mathrm{A}, \mathrm{U}$ and $\mathrm{U}$ were replaced by $\mathrm{G}, \mathrm{C}, \mathrm{C}$ and $\mathrm{C}$, respectively.

\section{DNA-DNA hybridization and $\mathbf{G}+\mathrm{C}$ content of genomic DNA}

DNA-DNA reassociation studies clearly revealed that all of the novel isolates investigated here belong to a single species whose members exhibit high levels of mutual relatedness (Table 2). Strains D7 and Ballarat
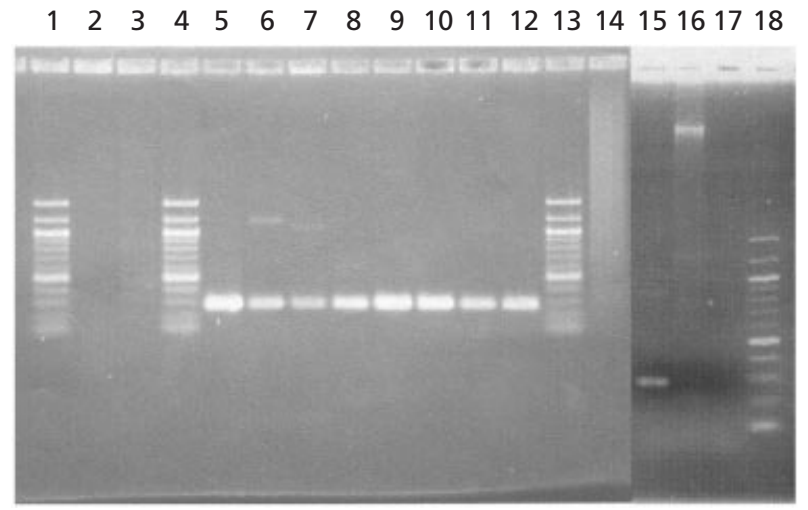

Fig. 1. DNA fingerprints obtained after using the REP-PCR technique from isolates D7 (lanes 5 and 15), 3 (lane 6), 6 (7), 7 (8), 13C2 (9), 38 (10), 83 (11), 118 (12) and Ballarat (16) and the reference strains $M$. luteus DSM $20030^{\top}$ (lane 2) and $M$. lylae DSM $20315^{\top}$ (3). Lanes 1, 4, 13 and 18, 100 bp ladder; lanes 14 and 17 , negative control.

had lower levels of DNA relatedness to M. lylae DSM $20315^{\mathrm{T}}$ than to $M$. luteus DSM $20030^{\mathrm{T}}$. Thus, DNADNA reassociation studies performed with the type strains $M$. luteus DSM $20030^{\mathrm{T}}$ and $M$. lylae DSM $20315^{\mathrm{T}}$ and strains D7, 3, 6, 7, 13C2, 38, 83, 118 and Ballarat clearly support the view that all of these novel isolates belong to the species $M$. luteus, as they exhibit DNA relatedness values above $70 \%$ (Table 2). The $\mathrm{G}+\mathrm{C}$ contents of the genomic DNAs of strains D7 and Ballarat were determined to be 71 and $70 \mathrm{~mol} \%$, respectively, which match the $\mathrm{G}+\mathrm{C}$ content of $M$. luteus perfectly (Stackebrandt et al., 1995).

\section{Analyses using the REP-PCR technique}

REP-PCR yielded one common band for isolates D7, $3,6,7,13 \mathrm{C} 2,38,83$ and 118 , whereas no such band was obtained for M. luteus DSM 20030 ${ }^{\mathrm{T}}$, M. lylae DSM $20315^{\mathrm{T}}$ or strain Ballarat (Fig. 1). As the possibility exists that PCRs may be inhibited by cell-wall fragments or other cell substances, a second primer pair, corresponding to the $16 \mathrm{~S}$ rDNA sequence, together with the REP primer set were subjected to PCR amplification. A PCR with these two primer sets generated two bands for strains D7, 3, 6, 7, 13C2, 38, 83 and 118 (the characteristic REP band at $300 \mathrm{bp}$ and the 16S rRNA band at $1500 \mathrm{bp}$ ). Only the characteristic 16S rDNA band was observed for M. luteus, $M$. lylae and strain Ballarat (data not shown), demonstrating that PCR amplification with the DNA of these strains was not inhibited.

\section{Chemotaxonomic features}

The three species M. luteus, M. lylae and M.antarcticus have been described as differing in some chemotaxonomic properties, including their polar lipids, fatty acid profiles, quinone systems and cell-wall compositions. However, our data suggest that the differ- 
Table 3. Fatty acid composition of M. luteus DSM $20030^{\top}, M$. lylae DSM $20315^{\top}$ and the novel isolates

Values are percentages of total fatty acids. Abbreviations for fatty acids are illustrated by the following examples: $\mathrm{C}_{16: 0}$, hexadecanoic acid; $\mathrm{i}-\mathrm{C}_{15: 0}, 13$-methyltetradecanoic acid; ai- $\mathrm{C}_{15: 0} ; 12$-methyltetradecanoic acid. tr, Trace.

\begin{tabular}{|c|c|c|c|c|c|c|c|c|c|c|c|}
\hline Fatty acid & $\begin{array}{c}\text { M. luteus } \\
\text { DSM 20030T }\end{array}$ & $\begin{array}{c}\text { M. lylae } \\
\text { DSM 20315 }\end{array}$ & D7 & 3 & 6 & 7 & $13 \mathrm{C} 2$ & 38 & 83 & 118 & Ballarat \\
\hline $\mathrm{i}-\mathrm{C}_{11: 0}$ & - & - & $\operatorname{tr}$ & $\operatorname{tr}$ & $0 \cdot 4$ & $\operatorname{tr}$ & 0.6 & $\operatorname{tr}$ & 0.5 & $\operatorname{tr}$ & - \\
\hline ai-C $C_{11: 0}$ & - & $\operatorname{tr}$ & $\operatorname{tr}$ & $\operatorname{tr}$ & $\operatorname{tr}$ & $\operatorname{tr}$ & $1 \cdot 0$ & $0 \cdot 5$ & $0 \cdot 6$ & 0.8 & - \\
\hline $\mathrm{i}-\mathrm{C}_{13: 0}$ & $\operatorname{tr}$ & $0 \cdot 5$ & $1 \cdot 0$ & $1 \cdot 5$ & $2 \cdot 6$ & $0 \cdot 3$ & $3 \cdot 0$ & 1.9 & $3 \cdot 1$ & $3 \cdot 1$ & - \\
\hline ai- $C_{13: 0}$ & $\operatorname{tr}$ & $0 \cdot 9$ & $1 \cdot 5$ & $3 \cdot 2$ & $1 \cdot 7$ & $1 \cdot 4$ & $5 \cdot 2$ & $2 \cdot 6$ & $3 \cdot 5$ & $5 \cdot 7$ & $1 \cdot 3$ \\
\hline $\mathrm{i}-\mathrm{C}_{14: 0}$ & $\operatorname{tr}$ & $2 \cdot 7$ & $2 \cdot 2$ & $3 \cdot 7$ & $2 \cdot 1$ & $2 \cdot 4$ & $2 \cdot 8$ & $2 \cdot 0$ & $3 \cdot 1$ & $3 \cdot 3$ & $1 \cdot 2$ \\
\hline $\mathrm{C}_{14: 0}^{14: 0}$ & $3 \cdot 7$ & $0 \cdot 8$ & $\operatorname{tr}$ & $1 \cdot 1$ & $0 \cdot 6$ & $0 \cdot 3$ & $1 \cdot 3$ & $1 \cdot 8$ & $2 \cdot 2$ & $0 \cdot 8$ & $3 \cdot 1$ \\
\hline $\mathrm{i}-\mathrm{C}_{15: 1}$ & $\operatorname{tr}$ & - & $\operatorname{tr}$ & $1 \cdot 0$ & $1 \cdot 3$ & $0 \cdot 4$ & $1 \cdot 4$ & $0 \cdot 7$ & $1 \cdot 1$ & - & - \\
\hline $\mathrm{i}-\mathrm{C}_{15: 0}$ & $37 \cdot 3$ & $26 \cdot 2$ & $28 \cdot 9$ & $15 \cdot 9$ & $30 \cdot 0$ & $14 \cdot 4$ & $29 \cdot 8$ & $29 \cdot 7$ & $29 \cdot 0$ & $13 \cdot 7$ & $26 \cdot 6$ \\
\hline ai- $C_{15: 0}$ & $52 \cdot 5$ & $59 \cdot 3$ & $63 \cdot 9$ & $70 \cdot 1$ & $58 \cdot 4$ & $78 \cdot 0$ & $53 \cdot 2$ & $56 \cdot 7$ & $51 \cdot 8$ & $70 \cdot 7$ & $61 \cdot 0$ \\
\hline $\mathrm{i}-\mathrm{C}_{16: 1}$ & $\operatorname{tr}$ & - & - & $\operatorname{tr}$ & $\operatorname{tr}$ & $\operatorname{tr}$ & $\operatorname{tr}$ & $\operatorname{tr}$ & 0.6 & - & - \\
\hline $\mathrm{i}-\mathrm{C}_{16: 0}$ & $\mathrm{tr}$ & $5 \cdot 0$ & $1 \cdot 4$ & $0 \cdot 9$ & $0 \cdot 7$ & $1 \cdot 6$ & $\operatorname{tr}$ & $1 \cdot 1$ & $1 \cdot 1$ & $0 \cdot 9$ & $1 \cdot 4$ \\
\hline $\mathrm{C}_{16: 0}$ & $2 \cdot 5$ & $0 \cdot 9$ & $\operatorname{tr}$ & $\operatorname{tr}$ & $\operatorname{tr}$ & $\operatorname{tr}$ & $\operatorname{tr}$ & $0 \cdot 8$ & $0 \cdot 8$ & $0 \cdot 9$ & - \\
\hline $\mathrm{C}_{16: 1} \omega 7 c$ & $4 \cdot 1$ & - & $\operatorname{tr}$ & $1 \cdot 1$ & $0 \cdot 8$ & $\operatorname{tr}$ & $1 \cdot 2$ & $1 \cdot 5$ & 1.9 & $\operatorname{tr}$ & - \\
\hline $\mathrm{i}-\mathrm{C}_{17: 0}$ & $\operatorname{tr}$ & $0 \cdot 7$ & $\operatorname{tr}$ & $\operatorname{tr}$ & $\operatorname{tr}$ & $\operatorname{tr}$ & $\operatorname{tr}$ & $\operatorname{tr}$ & $\operatorname{tr}$ & $\operatorname{tr}$ & - \\
\hline ai- $C_{17: 0}$ & $\operatorname{tr}$ & $3 \cdot 0$ & $1 \cdot 2$ & $\operatorname{tr}$ & $0 \cdot 6$ & $1 \cdot 2$ & $\operatorname{tr}$ & $0 \cdot 7$ & $\operatorname{tr}$ & $0 \cdot 7$ & - \\
\hline
\end{tabular}

ences in fatty acid profiles (Table 3 ) and polar lipid patterns of $M$. luteus DSM $20030^{\mathrm{T}}$ and M. lylae DSM $20315^{\mathrm{T}}$ are not as substantial as previously reported (Stackebrandt et al., 1995).

The cellular fatty acid profiles of our isolates were of the iso and anteiso methyl-branched-chain type, with $\mathrm{i}-\mathrm{C}_{15: 0}$ and ai- $\mathrm{C}_{15: 0}$ as the major components, accompanied by smaller, but significant, amounts of $i-$ $\mathrm{C}_{14: 0}$ and $\mathrm{i}-\mathrm{C}_{16: 0}$ (Table 3). The occurrence of straightchain saturated fatty acids was reported to distinguish $M$. luteus DSM $20030^{\mathrm{T}}$ from M. lylae DSM $200315^{\mathrm{T}}$ when acids constituting $<1 \%$ of the total were not taken into consideration (Stackebrandt et al., 1995). We have detected $\mathrm{C}_{14: 0}$ and $\mathrm{C}_{16: 0}$ fatty acids in the profile of M. lylae DSM $20315^{\mathrm{T}}$ at levels of 0.8 and $0.9 \%$, respectively. It is well known that quantification of certain fatty acids is hard to reproduce at levels of $1 \%$ and below, and this may lead to the misinterpretation of data for classification purposes. For example, the fatty acid profiles of strains $3,13 \mathrm{C} 2,38$ and 83 were all similar to that of $M$. luteus DSM $20030^{\mathrm{T}}$, whereas strains D7, 6, 7 and 118 exhibited fatty acid profiles close to that obtained from $M$. lylae DSM $20315^{\mathrm{T}}$ when amounts below $1 \%$ were ignored (Table 3).

Polar lipids also turned out to be unsuitable for differentiating Micrococcus species. In contrast to published data (Stackebrandt et al., 1995), our results demonstrated unambiguously that $M$. lylae DSM $20315^{\mathrm{T}}$ possesses small amounts of phosphatidylinositol in its polar lipid extract. All strains displayed identical polar lipid patterns, each possessing diphosphatidylglycerol, phosphatidylglycerol and phosphatidylinositol. Two unknown phospholipids and an unknown glycolipid were detected as well. Concentrations of phosphatidylinositol in strains D7, 3, 6, 7, $13 \mathrm{C} 2,38,83,118$ and Ballarat appeared to be higher than that observed for M. lylae DSM $20315^{\mathrm{T}}$ and lower than that detected for M. luteus DSM $20030^{\mathrm{T}}$.

Strains D7, 3, 6, 7, 13C2, 38, 83, 118 and Ballarat contained menaquinone MK- $8\left(\mathrm{H}_{2}\right)$ as the major quinone $(64-84 \%)$. Significant amounts of $\mathrm{MK}-7\left(\mathrm{H}_{2}\right)$ $(8-25 \%)$ and MK-9 $\left(\mathrm{H}_{2}\right)(3-12 \%)$ were also detected.

Cell-wall analysis was performed for strains D7, 3 and Ballarat, and, as expected, their diagnostic cell-wall diamino acid was L-lysine. However, strains D7 and 3 also contained alanine, glutamic acid and glycine. The molar ratio of these peptidoglycan amino acids (Ala: Glu: Gly: Lys) was $2 \cdot 1: 1 \cdot 1: 1 \cdot 1: 1 \cdot 0$ (strain D7). On the basis of amino acid and peptide analyses of cell-wall hydrolysates, strains D7 and 3 showed the peptidoglycan type of subgroup A2 according to Schleifer \& Kandler (1972), with L-lysine, a peptide subunit as the interpeptide bridge and glycine bound to the $\alpha$ carboxyl group of D-glutamic acid at position 2 of the peptide subunit. With strain Ballarat, the molar ratio of the peptidoglycan amino acids Ala:Glu:Gly:Lys: Asp was $1 \cdot 9: 1 \cdot 0: 1 \cdot 6: 0 \cdot 2: 0 \cdot 5$. The low contents of Asp and Lys were due to the occurrence of the peptide Asp $\rightarrow$ Lys, which is relatively stable under the conditions used for hydrolysis. In contrast to all other strains of $M$. luteus investigated, strain Ballarat possessed the peptidoglycan type A $4 \alpha$ L-Lys-Asp with glycine bound to the $\alpha$-carboxyl group of D-glutamic acid at position 2 of the peptide subunit (type A11.60 according to the 1998 DSMZ Catalogue of Strains), which has been found hitherto only in Arthrobacter 


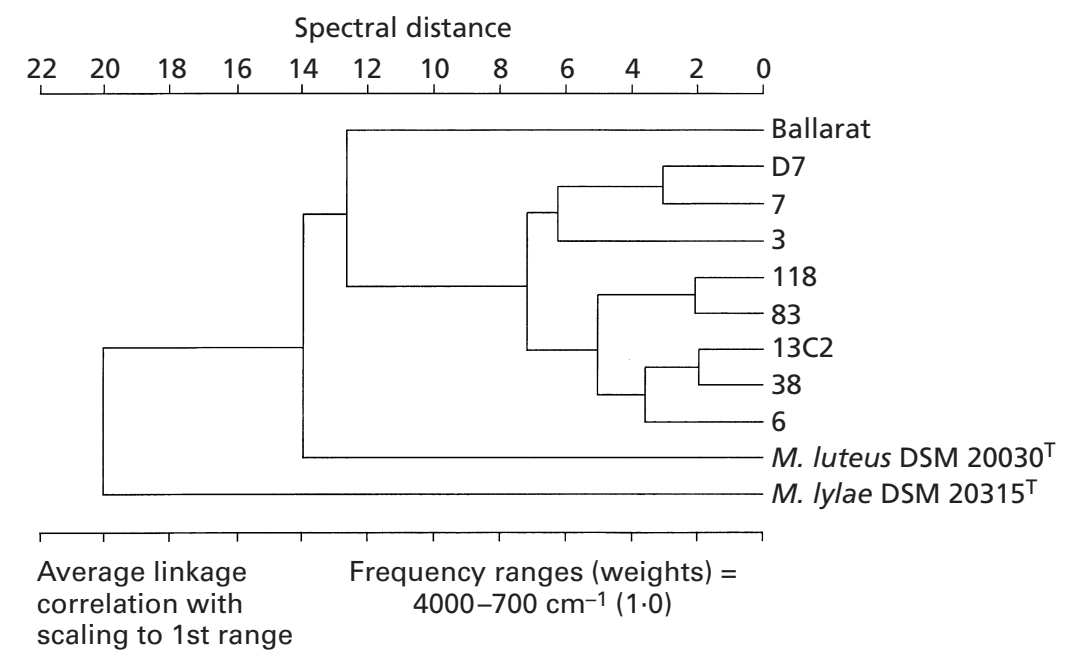

Fig. 2. Mean-linkage dendrogram based on distances of first derivatives of FT-IR spectroscopy spectra of $M$. lylae DSM $20315^{\top}, M$. luteus DSM $20030^{\top}$ and strains Ballarat, D7, 7, 3, 118, 83, 13C2, 38 and 6. The dendrogram was constructed using the spectral window $4000-700 \mathrm{~cm}^{-1}$.

woluwensis (Funke et al., 1996). However, strain Ballarat also appears to belong to the species $M$. luteus, on the basis of DNA relatedness, even though the peptidoglycan type A11.60 has never been observed for members of the species M. luteus. It should be noted that the interpeptide bridge of $M$. luteus DSM $20030^{\mathrm{T}}$ is structurally identical to the stem peptide in the peptidoglycan of strain Ballarat. In contrast, the stem peptides of $M$. lylae are linked via an aspartic acid residue. This suggests either that many strains of $M$. luteus are incapable of linking the stem peptides via a single amino acid (as is the case in M. lylae and strain Ballarat), but use a stem peptide to form the interpeptide bridge, or that the use of aspartic acid in the interpeptide bridge is an unusual feature of $M$. lylae and a few strains of $M$. luteus, since they cannot incorporate the peptide stem into the interpeptide bridge. It should be noted that the stem peptides of all $M$. luteus strains comprise alanine, glutamine, glycine and lysine, whereas glycine was absent from the cell walls of $M$. lylae. Published data on $M$. antarcticus also suggest that an A2-type cell wall, containing glycine, is present (Liu et al., 2000).

\section{FT-IR}

Comparison of FT-IR spectra revealed a high degree of similarity between strains D7, 3, 6, 7, 13C2, 38, 83 and 118. When dendrograms based on various combinations of spectral windows were analysed, these strains always formed one cluster (not shown); in all but a few cases, distance values between these spectra were below 10, which might indicate that they are indistinguishable (Helm et al., 1991a). Depending on the spectral window employed, the positions of strain Ballarat, M. luteus DSM $20030^{\mathrm{T}}$ and M. lylae DSM $20315^{\mathrm{T}}$ in the dendrograms relative to strains D7, 3, 6, 7, 13C2, 38, 83 and 118 did show some variation, $M$. lylae DSM $20315^{\mathrm{T}}$ or M. luteus DSM $20030^{\mathrm{T}}$ being more similar to the Micrococcus isolates investigated. This may not be significant, since the resolution of the FT-IR method may be at the intraspecific level (Tindall et al., 2000). The grouping of the investigated Micrococcus strains into three clusters was in good agreement with the groupings produced by the chemotaxonomic data. However, agreement of the clustering with the groups obtained from the other results was obtained when the dendrogram was calculated on the basis of the spectral window between wave numbers 4000 and $700 \mathrm{~cm}^{-1}$ (Fig. 2). This observation may indicate that the window employed here is suitable for identifying strains of $M$. luteus by using FT-IR.

\section{Considerations regarding heterogeneity in the species $M$. luteus}

On the basis of the results presented here, members of the species $M$. luteus appear to possess quite diverse chemotaxonomic features with respect to their menaquinone systems, cell-wall compositions and FT-IR patterns, as well as biochemical properties. To our knowledge, no single bacterial species has been described that is characterized by such large differences in its quinone system and its peptidoglycan type. It should be noted that a survey of the literature indicates that members of a single species (when supported by DNA-DNA hybridization and phenotypic properties) usually provide us with a picture of a complex of strains highly similar in their phenotypic and genotypic properties. Such intraspecific differences as documented here have not been reported previously. However, despite the fact that our data may appear to contradict the widely accepted view of what constitutes a species, it should be pointed out that we do not know which mechanisms are responsible for the apparently significant variations in the quantitative menaquinone composition and qualitative peptidoglycan structure. It should also be pointed out that species tend to be regarded as static units, when they are, in fact, dynamic units that change over geological time. Normally, such changes are barely perceived by us, but examples of subdivisions within a single species, such as in the data presented here, may provide interesting evidence of a 'snapshot' of evolutionary change taking place. 
Among the authors of this paper, there have been many discussions concerning how to treat the heterogeneity within the species $M$. luteus. One solution would have been to dissect the species $M$. luteus into three subspecies, but this would be premature. Whilst we wish to recognize the heterogeneity within the group, we felt that it would not be appropriate to give these groups subspecies status; instead, we elected to divide them, on a formal basis, into three different biovars. The recognition of three different biovars within the species $M$. luteus has the advantage that the three groups can be differentiated without nomenclatural changes having to be introduced. The results we have presented, and the conclusions we have drawn, indicate that a closer study of a larger number of isolates from the different species within the genus Micrococcus and from the different biovars within the species $M$. luteus may provide an interesting insight into the diversity within this group of organisms. On the basis of the data presented here, we propose the dissection of the species $M$. luteus into three biovars, as follows: biovar I, represented by $M$. luteus DSM $20030^{\mathrm{T}}$ [peptidoglycan type A2, predominant quinones MK- 8 and MK-8( $\left.\mathrm{H}_{2}\right)$; biovar II, represented by strains D7, 3, 6, 7, 13C2, 38, 83 and 118 [peptidoglycan type $\mathrm{A} 2$, predominant quinone $\left.\mathrm{MK}-8\left(\mathrm{H}_{2}\right)\right]$; and biovar III, represented by strain Ballarat [peptidoglycan type $\mathrm{A} 4 \alpha$, predominant quinone $\left.\mathrm{MK}-8\left(\mathrm{H}_{2}\right)\right]$. Consequently, only selected physiological and biochemical properties appear to remain suitable for differentiating between $M$. luteus and M. lylae strains (Table 1).

On the basis of the results generated in this study, emended descriptions of the genus Micrococcus and the species $M$. luteus and M. lylae are presented.

\section{Emended description of the genus Micrococcus Cohn $1872,151^{\mathrm{AL}}$, emend. Stackebrandt et al. 1995, 691}

In addition to the properties given in the genus description (Stackebrandt et al., 1995), members of the genus Micrococcus show several common characteristics. Growth occurs up to $\mathrm{pH} 10$. The polar lipids are phosphatidylglycerol, diphosphatidylglycerol, phosphatidylinositol, an unknown glycolipid and an unknown ninhydrin-negative phospholipid. L-Arabinose, $p$-arbutin, D-cellobiose, D-galactose, D-melibiose, D-ribose and salicin are not assimilated. Members of the genus share the Micrococcaceae-specific signature nucleotides at positions 293-304, 610, 598, 615-625, 1025-1036, 1026-1035, 1265-1270 and 1278 of the $16 \mathrm{~S}$ rRNA gene sequence (E. coli numbering) and lack the signature nucleotides at positions $640,839-847$ and 859 (Stackebrandt et al., 1997).

\section{Emended description of Micrococcus luteus (Schroeter) Cohn 1872, 153 ${ }^{\mathrm{AL}}$ (synonym: 'Bacteridium luteum' Schroeter 1872, 126)}

In addition to the properties given in the genus description above and the original species description, members of this species have the following char- acteristics. Growth or weak growth is observed at $45^{\circ} \mathrm{C}$, at $\mathrm{pH} 10$ and in the presence of $10 \% \mathrm{NaCl}$; no growth is observed in the presence of $15 \% \mathrm{NaCl}$. Urease-variable. D-Glucose, sucrose and D-mannose are assimilated. D-Fructose, $N$-acetyl-D-glucosamine, L-rhamnose, gluconate, cis-aconitate, trans-aconitate, adipate, azelate, itaconate, mesaconate, suberate, $\beta$-alanine, L-ornithine, L-tryptophan, L-leucine, 3hydroxybenzoate and 4-hydroxybenzoate are not assimilated. $p$-Nitrophenyl (pNP) $\alpha$-glucopyranoside and L-alanine $p$-nitroanilide (pNA) are hydrolysed. pNP D-Galactopyranoside, $p N P$ D-glucuronide, $p N P$ D-glycopyranoside, bis-pNP phosphate, pNP phenylphosphate, pNP phosphorylcholine, 2-deoxythymidine-5'-pNP phosphate and L-glutamate-3carboxy pNA are not hydrolysed. The peptidoglycan variation is either $\mathrm{A} 2$ or $\mathrm{A} 4 \alpha$. The predominant menaquinones are either MK-8 and MK-8 $\left(\mathrm{H}_{2}\right)$ or MK-8 $\left(\mathrm{H}_{2}\right)$ alone. MK-7 or MK-7 $\left(\mathrm{H}_{2}\right)$ and MK- $9\left(\mathrm{H}_{2}\right)$ and MK-6 $\left(\mathrm{H}_{2}\right)$ occur in minor amounts.

\section{M. luteus biovar I}

In addition to the properties given in the species description, members of this biovar have the following characteristics. No growth is observed at $\mathrm{pH} 6$. Ureasepositive. Maltitol, L-aspartate and propionate are assimilated. D-Maltose, D-trehalose, D-xylose, adonitol, $i$-inositol, D-mannitol, D-sorbitol, putrescine, acetate, 4-aminobutyrate, citrate, fumarate, glutarate, DL-3-hydroxybutyrate, DL-lactate, L-malate, oxoglutarate, pyruvate, L-alanine, L-histidine, L-phenylalanine, L-proline, L-serine and phenylacetate are not assimilated. L-Proline pNA and Tween 20 are hydrolysed. Casein and Tween 80 are not hydrolysed. The peptidoglycan type is A2. The major menaquinones are MK- 8 and MK- $8\left(\mathrm{H}_{2}\right)$. The reference strain for this biovar is the designated type strain for this species, $M$. luteus DSM 20030 ${ }^{\mathrm{T}}$.

\section{M. luteus biovar II}

In addition to the properties given in the species description, members of this biovar have the following characteristics. Colonies are creamy yellow in colour, circular, entire and convex. Growth at $\mathrm{pH} 6.0$ is variable. Urease-variable. D-Maltose, D-trehalose, acetate, propionate, DL-3-hydroxybutyrate, DLlactate, pyruvate, L-histidine, L-phenylalanine, L-serine and phenylacetate are assimilated. Oxoglutarate is not assimilated. Assimilation of $\mathrm{D}$-xylose, adonitol, $i$ inositol, maltitol, D-mannitol, D-sorbitol, putrescine, 4-aminobutyrate, citrate, fumarate, glutarate, L-malate, L-alanine, L-aspartate and L-proline is variable. Casein and L-proline pNA are hydrolysed. Hydrolysis of Tween 20 and Tween 80 is variable. The peptidoglycan type is A2. The major menaquinone is $\mathrm{MK}$ $8\left(\mathrm{H}_{2}\right)$. The $\mathrm{G}+\mathrm{C}$ content of the DNA of reference strain D7 is $71 \mathrm{~mol} \%$. Strains were isolated from a medieval wall painting and from indoor air. The reference strain for biovar II is strain D7 (= DSM 14234 = CCM 4959). 


\section{M. luteus biovar III}

In addition to the properties given in the species description, the single member of this biovar has the following characteristics. Colonies are creamy yellow in colour, circular, entire and convex. No growth is observed at pH 6.0. Urease-positive. D-Maltose, Dtrehalose, 4-aminobutyrate, fumarate, DL-3-hydroxybutyrate, DL-lactate, oxoglutarate, pyruvate, L-histidine and L-proline are assimilated. D-Xylose, adonitol, $i$-inositol, maltitol, D-mannitol, D-sorbitol, putrescine, acetate, propionate, citrate, glutarate, L-malate, Lalanine, L-aspartate, L-phenylalanine, L-serine and phenylacetate are not assimilated. Tween 20 and casein are hydrolysed. L-Proline pNA and Tween 80 are not hydrolysed. The main menaquinone is $\mathrm{MK}-8\left(\mathrm{H}_{2}\right)$. The peptidoglycan variation is $A 4 \alpha$. The $G+C$ content of the DNA of the reference strain is $70 \mathrm{~mol} \%$. Strain Ballarat was isolated from an activated-sludge plant in Ballarat, Victoria, Australia. The reference strain for biovar III is strain Ballarat (= DSM $14235=$ CCM 4960).

\section{Emended description of Micrococcus lylae (Kloos, Tornabene and Schleifer 1974, 83 ${ }^{\mathrm{AL}}$ )}

In addition to the properties given in the genus description above and the original species description, this species has the following characteristics. D-Glucose, sucrose, D-fructose, D-maltose, D-trehalose, maltitol, acetate, citrate, fumarate, DL-3-hydroxybutyrate, DL-lactate, pyruvate, L-aspartate, L-histidine, L-leucine, 3-hydroxybenzoate and 4-hydroxybenzoate are assimilated. D-Mannose, D-xylose, adonitol, $i$-inositol, D-mannitol, D-sorbitol, $N$-acetyl-D-glucosamine, Lrhamnose, gluconate, cis-aconitate, trans-aconitate, adipate, azelate, itaconate, mesaconate, suberate, putrescine, propionate, glutarate, L-malate, oxoglutarate, 4-aminobutyrate, $\quad$-ornithine, $\quad$-tryptophan, $\beta$ alanine, L-alanine, L-phenylalanine, L-proline, L-serine and phenylacetate are not assimilated. pNP $\alpha$-Glucopyranoside, L-alanine pNA, L-proline pNA, Tween 20 and Tween 80 are hydrolysed. pNP D-Galactopyranoside, pNP D-glucuronide, pNP D-glycopyranoside, bis-pNP phosphate, pNP phenylphosphate, pNP phosphorylcholine, 2-deoxythymidine-5'-pNP phosphate, L-glutamate-3-carboxy pNA and casein are not hydrolysed. The main menaquinone is $\mathrm{MK}$ $8\left(\mathrm{H}_{2}\right)$. The peptidoglycan variation is $\mathrm{A} 4 \alpha$.

\section{ACKNOWLEDGEMENTS}

This work was supported by the European Commission R\&D program 'Environment and Climate', contract no. ENV4-CT95-088, and by grants from the Austrian Fonds zur Förderung der Wissenschaftlichen Forschung (P9099MOB and P10730-MOB).

\section{REFERENCES}

Baird-Parker, A. C. (1965). The classification of staphylococci and micrococci from world-wide sources. J Gen Microbiol 38, 363-387.
Brosius, J., Palmer, M. L., Kennedy, P. J. \& Noller, H. F. (1978). Complete nucleotide sequence of a $16 \mathrm{~S}$ ribosomal RNA gene from Escherichia coli. Proc Natl Acad Sci U S A 75, 4801-4805.

Camuffo, D., Brimblecombe, P., Van Grieken, R. \& 10 other authors (1999). Indoor air quality at the Correr museum, Venice, Italy. Sci Total Environ 236, 135-152.

Cohn, F. (1872). Untersuchungen über Bakterien. Beitr Biol Pflanz 1, 127-244.

Faller, A. \& Schleifer, K. H. (1981). Modified oxidase and benzidine tests for separation of staphylococci from micrococci. J Clin Microbiol 13, 1031-1035.

Funke, G., Hutson, R. A., Bernard, K. A., Pfyffer, G. E., Wauters, G. \& Collins, M. D. (1996). Isolation of Arthrobacter spp. from clinical specimens and description of Arthrobacter cumminsii sp. nov. and Arthrobacter woluwensis sp. nov. J Clin Microbiol 34, 2356-2363.

Groth, I., Schumann, P., Weiss, N., Martin, K. \& Rainey, F. A. (1996). Agrococcus jenensis gen. nov., sp. nov., a new genus of actinomycetes with diaminobutyric acid in the cell wall. Int $J$ Syst Bacteriol 46, 234-239.

Helm, D., Labischinski, H., Schallehn, G. \& Naumann, D. (1991a). Classification and identification of bacteria by Fourier-transform infrared spectroscopy. J Gen Microbiol 137, 69-79.

Helm, D., Labischinski, H. \& Naumann, D. (1991b). Elaboration of a procedure for identification of bacteria using Fourier-transform IR spectral libraries: a stepwise correlation approach. J Microbiol Methods 14, 127-142.

Huys, G., Kämpfer, P., Altwegg, M. \& 7 other authors (1997). Aeromonas popoffii sp. nov. a mesophilic bacterium isolated from drinking water production plants and reservoirs. Int J Syst Bacteriol 47, 1165-1171.

Kämpfer, P., Steiof, M. \& Dott, W. (1991). Microbiological characterization of a fuel oil contaminated site including numerical identification of heterotrophic water and soil bacteria. Microb Ecol 21, 227-251.

Kaneko, T., Katoh, K., Fujimoto, M., Kumagati, J., Tamaoka, J. \& Katayama-Fujimura, Y. (1986). Determination of the nucleotide composition of a deoxyribonucleic acid by high-performance liquid chromatography of its enzymatic hydrolysates: a review. $J$ Microbiol Methods 4, 229-240.

Kloos, W. E., Tornabene, T. G. \& Schleifer, K. H. (1974). Isolation and characterization of micrococci from human skin, including two new species: Micrococcus lylae and Micrococcus kristinae. Int J Syst Bacteriol 24, 79-101.

Kocur, M., Schleifer, K. H. \& Kloos, W. E. (1975). Taxonomic status of Micrococcus nishinomiyaensis Oda 1935. Int J Syst Bacteriol 25, 290-293.

Liu, H., Xu, Y., Ma, Y. \& Zhou, P. (2000). Characterization of Micrococcus antarcticus sp. nov., a psychrophilic bacterium from Antarctica. Int J Syst Evol Microbiol 50, 715-719.

Louws, F. J., Fulbright, D. W., Stephens, C. T. \& de Bruijn, F. J. (1994). Specific genomic fingerprints of phytopathogenic Xanthomonas and Pseudomonas pathovars and strains generated with repetitive sequences and PCR. Appl Environ Microbiol 60, 2286-2295.

Maszenan, A. M., Seviour, R. J., Patel, B. K. C., Rees, G. N. \& McDougall, B. M. (1997). Amaricoccus gen. nov., a Gram-negative coccus occurring in regular packages or tetrads, isolated from activated sludge biomass, and descriptions of Amaricoccus veronensis sp. nov., Amaricoccus tamworthensis sp. nov., Amaricoccus macauensis sp. nov., and Amaricoccus kaplicensis sp. nov. Int J Syst Bacteriol 47, 727-734.

Moaledj, K. (1986). Comparison of Gram-staining and alternate methods, $\mathrm{KOH}$ test and aminopeptidase activity in aquatic bacteria: their application to numerical taxonomy. J Microbiol Methods 5, 303-310.

Nielson, P., Fritze, D. \& Priest, F. G. (1995). Phenetic diversity of alkaliphilic Bacillus strains: proposal for nine new species. Microbiology 141, 1745-1761.

Onishi, H. \& Kamekura, M. (1972). Micrococcus halobius sp. n. Int J Syst Bacteriol 22, 233-236. 
Rosypal, S., Rosypalová, A. \& Hořejš, J. (1966). The classification of micrococci and staphylococci based on their DNA base composition and Adansonian analysis. J Gen Microbiol 44, 281-292.

Schleifer, K. H. \& Kandler, O. (1972). Peptidoglycan types of bacterial cell walls and their taxonomic implications. Bacteriol Rev 36, 407-477.

Schleifer, K. H., Heise, W. \& Meyer, S. A. (1979). Deoxyribonucleic acid hybridization studies among some micrococci. FEMS Lett $\mathbf{6}$, 33-36.

Smibert, R. M. \& Krieg, N. R. (1994). Phenotypic characterization. In Methods for General and Molecular Microbiology, pp. 611-654. Edited by P. Gerhard, R. G. Murray, W. A. Wood \& N. R. Krieg. Washington, DC: American Society for Microbiology.

Stackebrandt, E., Koch, C., Gvozdiak, O. \& Schumann, P. (1995). Taxonomic dissection of the genus Micrococcus: Kocuria gen. nov.,
Nesterenkonia gen. nov., Kytococcus gen. nov., Dermacoccus gen. nov., and Micrococcus Cohn 1872 gen. emend. Int J Syst Bacteriol 45, 682-692.

Stackebrandt, E., Rainey, F. A. \& Ward-Rainey, N. L. (1997). Proposal for a new hierarchic classification system, Actinobacteria classis nov. Int J Syst Bacteriol 47, 479-491.

Tindall, B. J., Brambilla, E., Steffen, M., Neumann, R., Pukall, R., Kroppenstedt, R. M. \& Stackebrandt, E. (2000). Cultivatable microbial biodiversity: gnawing at the Gordian knot. Environ Microbiol 2, 310-318.

Wieser, M., Schumann, P., Martin, K., Altenburger, P., Burghardt, J., Lubitz, W. \& Busse, H.-J. (1999). Agrococcus citreus sp. nov., isolated from a medieval wall painting of the chapel of Castle Herberstein (Austria). Int J Syst Bacteriol 49, 1165-1170. 